\title{
POLA KOMUNIKASI ORGANISASI KEMAHASISWAAN DALAM PENERAPAN AJARAN WACIKA PARISUDHA
}

\author{
Ni Kadek Tia Wiat Wilantari, Si Luh Nyoman Seriadi \\ Jurusan Pendidikan Bahasa Inggris, Fakultas Dharma Acarya \\ Universitas Hindu Negeri I Gusti Bagus Sugriwa Denpasar \\ kadektia18@gmail.com, nyomanseriadiihdn@gmail.com
}

\section{ABSTRACT}

The communication pattern is a model of the communication process and also the part of the communication process. Communication pattern is important in communication, especially in student organization. Student organization is a tool of self-development for students that have many benefits, including broadening students 'horizons, increasing intelligence and students' personal integrity in adressing campus, community, and national problems. The communication pattern used in student organization is the communication pattern of all channels or stars. Star-structured communication patterns apply to all activities such as meetings and interactions outside o meetings that are formal or informal. In using communication pattern all chanels or stars that give equal rights to all members of the organization must not escape the application of the Wacika Parisudha. keeping the words in the organization is something that cannot be separated either in using any communication patterns. There are two factors that support the success of the student organization communicationn pattern in the application of Wacika Parisudha which are classified into two, namely internal and external factors. As for the internal factor that support the success of a communication between members of the student organization in the application of Wacika Parisudha, namely the awareness of each individual student who participates in the student organization that it is very important to maintain wards in following an organization. While external factor that support the success of a communication between members of student organization in the application of Wacika Parisudha are the rules or norms applied in the organization and also the leader or administrators in the organization or it can also be called as the organizational environment.

Keywords: Communication Pattern, Student Organization, Wacika Parisudha

\begin{abstract}
ABSTRAK
Pola komunikasi merupakan model dari proses komunikasi dan bagian dari proses komunikasi. Pola komunikasi merupakan hal penting dalam komunikasi terutama dalam organisasi kemahasiswaan. Organisasi kemahasiswaan merupakan sarana bagi pengembangan diri mahasiswa yang memiliki banyak manfaat, diantaranya memperluas wawasan mahasiswa, meningkatkan kecendikiawanan, serta meningkatkan integritas pribadi mahasiswa dalam menyikapi permasalahan kampus, masyarakat dan bangsa. Pola komunikasi
\end{abstract}


yang digunakan dalam organisasi kemahasiswaan adalah pola komunikasi semua saluran atau bintang. Pola komunikasi berstruktur bintang berlaku pada seluruh kegiatan seperti rapat dan interaksi diluar rapat yang sifatnya formal maupun informal. Dalam menggunakan pola komunikasi semua saluran atau bintang yang memberikan hak sama kepada semua anggota organisasi tidak boleh lepas dari penerapan ajaran Wacika Parisudha. Menjaga perkataan dalam organisasi merupakan hal yang tidak boleh dilepaskan baik dalam menggunakan pola komunikasi apapun. Terdapat dua faktor yang mendukung keberhasilan Pola Komunikasi Organisasi Kemahasiswaan dalam Penerapan Ajaran Wacika Parisudha yang diklasifikasikan menjadi dua, yakni faktor internal dan eksternal. Adapun faktor internal yang mendukung keberhasilan suatu komunikasi antar anggota organisasi kemahasiswaan dalam penerapan Ajaran Wacika Parisudha yaitu kesadaran dari setiap individu mahasiswa yang mengikuti organisasi kemahasiswaan tersebut bahwa sangat penting untuk menjaga perkataan dalam mengikuti sebuah organisasi. Sedangkan faktor eksternal yang mendukung keberhasilan suatu komunikasi antar anggota organisasi kemahasiswaan dalam penerapan Ajaran Wacika Parisudha ialah peraturan atau norma yang diterapkan dalam organisasi dan juga para pemimpin atau pengurus dalam organisasi itu sendiri atau bisa juga disebut sebagai lingkungan organisasi.

Kata Kunci: Pola Komunikasi, Organisasi Kemahasiswaan, Wacika Parisudha

\section{PENDAhUluaN}

Komunikasi merupakan hal terpenting dalam kehidupan manusia, menurut pandangan beberapa sumber bahwa manusia bisa bertahan dan berkembang berkat adanya komunikasi. Menurut Dewey dalam Pakumara dkk (2017: 1), melalui komunikasi manusia dapat saling berinteraksi dan saling berhubungan dengan manusia lain dalam kehidupannya. Manusia dalam kehidupannya selalu melakukan interaksi dan komunikasi dengan manusia lainnya sebab manusia merupakan makhluk sosial yang tidak dapat hidup sendiri. Oleh karena itu, manusia diharuskan membina hubungan baik dengan manusia lainnya dan hal itu bisa dicapai melalui kemampuan berkomunikasi yang baik. Puspa dkk (2020: 133) menyatakan bahwa komunikasi merupakan suatu tindakan seseorang untuk dapat memberikan atau menerima informasi dari orang lain tentang kebutuhan, persepsi, pengetahuan, atau keinginan. Puspa dkk (2020: 133) juga menambahkan bahwa komunikasi biasanya didukung oleh upaya manusia untuk dapat beradaptasi dengan lingkungan sekitarnya dalam bermasyarakat agar manusia dapat hidup serta dapat mempertahankan keberadaannya dalam suasana yang harmonis di tengah masyarakat. Hal ini jelas menunjukkan bahwa komunikasi memang benar adanya tidak dapat dipisahkan dari kehidupan umat manusia baik secara individu maupun kelompok.

Pada era seperti saat ini pengalaman dalam organisasi itu merupakan hal yang penting dilakukan. Oleh sebab itu, baik dalam ranah sekolah maupun kampus sudah banyak terdapat organisasi-organisasi kemahasiswaan. Menurut Arikunto dalam Bukhori (2016: 166), organisasi merupakan sistem kerjasama antara beberapa orang dalam mencapai tujuan bersama. Menurut pendapat lainnya yang diutarakan oleh Hayati dalam Bukhori (2016: 166), menyatakan bahwa organisasi sebagai kelompok orang-orang yang berkumpul untuk meraih 
tujuan bersama. Menurut Hardjito dalam Bukhori (2016: 166) organisasi juga dapat diartikan sebagai satu kesatuan sosial yang diatur agar terarah guna pencapaian suatu tujuan yang tidak bisa diwujudkan secara personal sehingga harus tergabung dalam satu wadah bersama. Organisasi kemahasiswaan merupakan suatu bentuk kelompok dari beberapa mahasiswa dengan suatu koordinasi yang melakukan suatu kegiatan untuk mencapai tujuan tertentu yang telah ditetapkan Bukhori (2016: 167). Dengan kata lain, dalam organisasi terdapat suatu hubungan atau interaksi antara anggota yang satu dengan anggota yang lain untuk melakukan suatu kerjasama demi tercapainya suatu tujuan. Dalam organisasi kemahasiswaan komunkasi yang baik adalah kunci untuk mencapai tujuan organisasi yang telah ditetapkan. Komunikasi yang baik sangat penting diterapkan dalam sebuah organisasi. Dalam ajaran agama Hindu terdapat landasan yang dijadikan dasar dalam berpikir, berkata, dan berbuat yang biasa disebut Tri Kaya Parisudha. Dalam kaitannya dengan komunikasi bagian Tri Kaya Parisudha yang sesuai adalah pada bagian Wacika Parisudha. Wacika Parisudha yang berarti perkataan yang baik. wacika Parisudha sangat perlu diterapkan dalam komunikasi organisasi, dengan kata-kata atau perkataan yang baik maka akan bisa menciptakan hubungan yang baik pula antara satu individu dengan individu lainnya atau dalam suatu kelompok organisasi seperti organisasi kemahasiswaan. Wacika Parisudha sebagai ajaran dasar agama Hindu yang tampak sederhana yang dapat diterapkan sehari-hari namun, memiliki potensi besar dalam membina hubungan dalam organisasi kemahasiswaan.

\section{PEMBAHASAN}

2.1 Pola Komunikasi Organisasi Kemahasiswaan

\subsubsection{Pola Komunikasi}

Pola komunikasi merupakan model dari proses komunikasi dan juga pola komunikasi merupakan bagian dari proses komunikasi. Dalam konsep De Vito terdapat lima model pola komunikasi yang digunakan membatasi aliran komunikasi dalam organisasi, yaitu: pola model lingkaran, pola model roda, pola model rantai, pola model $Y$, dan model semua saluran atau bintang De Vito dalam Pakumara dkk (2017: 2). Pola komunikasi organisasi merupakan bagian yang sangat penting dalam penyampaian informasi dari seorang pimpinan kepada anggotanya, yaitu meliputi sumber informasi, sebagai pusat ingatan bagi organisasi dan penciptaan gagasan atau ide-ide agar dapat mencapai tujuan yang diinginkan dalam suatu organisasi kemahasiswaan. Secara rinci akan dibahas sebagai berikut:

1) Roda

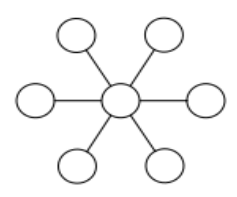


Pola roda merupakan komunikasi dengan dua saluran, di mana setiap anggota akan mengirim dan menerima pesan ke pusat komunikasi, dan pusat komunikasi akan menerima serta mendistribusikan informasi yang diterimanya. Pada contoh bentuk roda ini, pimpinan biasanya merupakan sumber komunikasi, ia dapat mengirimkan informasi ke semua anggotanya. Masing-masing anggota dapat mengirim pesan jaringan yang menggambarkan situasi di mana kedua anggota pada bagian ujung rantai hanya dapat berkomunikasi dengan orang di antara mereka dan orang yang berada di pusat. Dengan demikian, kedua orang yang berada di tengah-tengah menyampaikan informasi ke atas. Pola komunikasi tersebut jelas mempunyai dampak terhadap organisasi.

2) $\mathrm{Y}$

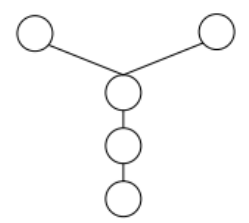

Pada pola Y ini pusat komunikasi tidak dapat berkomunikasi langsung dengan seluruh individu, tetapi ada individu yang komunikasinya harus melalui individu lain.

3) Rantai (Chain)

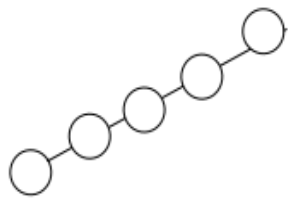

Pola rantai hampir sama dengan pola lingkaran, hanya saja di sini ada dua individu yang berada di akhir jaringan, sehingga hanya dapat mengirim dan menerima pesan dari satu posisi.

4) Lingkaran

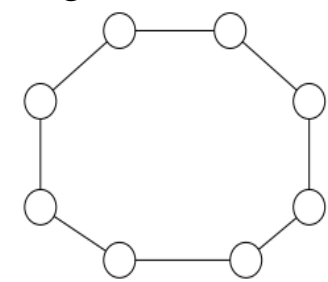

Pola komunikasi lingkaran memungkinkan masing-masing individu untuk mengirim pesan ke sebelah kiri atau ke sebelah kanannya. Namun demikian individu tidak dapat mengirim dan menerima pesan secara langsung ke seluruh anggota.

5) Semua Saluran atau Bintang

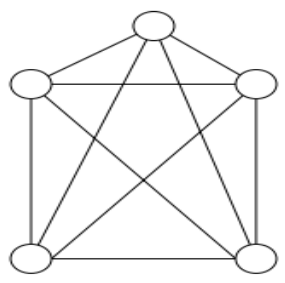


Pada jaringan semua arah, semua individu pada semua posisi dimungkinkan untuk mengirim dan menerima informasi ke segala arah. Jaringan, struktur, pola ini digunakan untuk menentukan tipe interaksi antara individu dalam organisasi.

\subsubsection{Komunikasi Organisasi}

Wayne Pace dan Don F. Faules dalam Putra dan Ghofur (2018: 64) mengklasifikasikan definisi komunikasi organisasi menjadi dua, yakni definisi fungsional dan definisi interpretative. Definisi fungsional komunikasi organisasi adalah sebagai pertunjukan dan penafsiran pesan di antara unit-unit komunikasi yang merupakan bagian dari suatu organisasi tertentu. Suatu organisasi terdiri dari unit-unit komunikasi dalam hubungan-hubungan hierarkis antara yang satu dengan yang lainnya dan berfungsi dalam suatu lingkungan. Sedangkan definisi interpretative komunikasi organisasi cenderung menekankan pada kegiatan penanganan pesan yang terkandung dalam suatu batas organisasional. Dengan kata lain adalah proses penciptaan makna atas interaksi yang menciptakan, memelihara, dan mengubah organisasi. Jadi, perspektif interpretative menekankan peranan orang-orang dan proses dalam menciptakan makna. Makna tersebut tidak hanya pada orang, namun juga dalam transaksi itu sendiri. Sifat terpenting komunikasi organisasi adalah penciptaan pesan, penafsiran, dan penanganan kegiatan organisasi. Bagaimana komunikasi berlangsung dalam organisasi dan apa maknanya bergantung pada konsepsi seseorang mengenai organisasi. Komunikasi organisasi dapat dilihat sebagai proses untuk mengumpulkan, menyimpan, memproses, dan menyebarkan komunikasi yang memungkinkan untuk keberlangsungan organisasi tersebut, Farace, Monge \& Russel dalam Pakumara dkk (2017: 1). Pakumara dkk (2016: 2) menyatakan bahwa komunikasi organisasi adalah pengiriman dan penerimaan berbagai pesan organisasi di dalam kelompok formal maupun informal dari suatu organisasi. Komunikasi organisasi memiliki empat fungsi, yaitu sebagai berikut:

\section{1) Fungsi Informatif}

Organisasi dapat dipandang sebagai suatu sistem pemrosesan informasi. Maksudnya, seluruh anggota dalam organisasi berharap dapat memperoleh informasi yang lebih banyak, lebih baik dan tepat waktu. Informasi yang didapat memungkinkan setiap anggota organisasi dapat melaksanakan pekerjaannya secara lebih pasti. Informasi pada dasarnya dibutuhkan oleh semua orang yang mempunyai perbedaan kedudukan dalam suatu organisasi, Pratala (2018: 53).

\section{2) Fungsi Regulatif}

Fungsi ini berkaitan dengan peraturan-peraturan yang berlaku dalam organisasi. Pengaruhnya terhadap organisasi yaitu pimpinan yang berada dalam tataran manajemen memiliki kewenangan mengendalikan semua informasi yang disampaikan, kewenangan dalam memberi instruksi atau perintah, sehingga dalam struktur 
organisasi kemungkinan mereka ditempatkan pada lapisan atas supaya perintah dilaksanakan sebagaimana mestinya, Pratala (2018: 53).

\section{3) Fungsi Persuasif}

Dalam mengatur organisasi, kekuasaan dan kewenangan tidak akan selalu membawa hasil sesuai dengan yang diharapkan. Adanya kenyataan ini, maka banyak pimpinan yang lebih suka untuk mempersuasi anggotanya daripada memberi perintah. Sebab pekerjaan yang dilakukan secara sukarela oleh anggota akan menghasilkan kepedulian yang lebih besar dibanding apabila pemimpin sering memperlihatkan kekuasaan dan kewenangannya, Pratala (2018: 53).

\section{4) Fungsi Integratif}

Setiap organisasi berusaha untuk menyediakan saluran yang memungkinkan anggota dapat melaksanakan tugas dan pekerjaan dengan baik. Terdapat dua saluran komunikasi yaitu saluran komunikasi formal (news letter, bulletin, email ) dan saluran komunikasi informal (perbincangan antar pribadi, masa istirahat kerja, dll), Wina, Senjaya, dalam Pratala (2018: 53).

\subsubsection{Organisasi Kemahasiswaan}

Dalam Peraturan Pemerintah Nomor 30 pasal 108 ayat 1 dinyatakan bahwa "Untuk melaksanakan peningkatan penalaran, minat, kegemaran, dan kesejahteraan mahasiswa dalam kehidupan kemahasiswaan pada perguruan tinggi dibentuk organisasi kemahasiswaan" (Kepmen Diknas. 2000). Organisasi kemahasiswaan merupakan sarana bagi pengembangan diri mahasiswa yang memiliki banyak manfaat, diantaranya memperluas wawasan mahasiswa, meningkatkan kecendikiawanan, serta meningkatkan integritas pribadi mahasiswa dalam menyikapi permasalahan kampus, masyarakat dan bangsa, Oviyanti (2016: 64). Manfaat lain yang dapat diperoleh mahasiswa dengan aktif pada organisasi kemahasiswaan intrakampus adalah berkembangnya kemampuan bekerja sama, ketrampilan berorganisasi serta kemampuan berkomunikasi dan ketrampilan khusus yang sesuai dengan bidang atau jenis organisasi kemahasiswaan yang diikuti, Oviyanti (2016: 64).

\subsubsection{Media Komunikasi dalam Organisasi Kemahasiswaan}

Proses penyampaian pesan atau informasi agar menjadi efektif dibutuhkan media komunikasi sebagai penyalur proses penyampaian pesan. Saluran komunikasi berupa media sangat berperan penting di dalam organisasi kemahasiswaan karena dengan adanya saluran komunikasi dapat memudahkan proses komunikasi antar anggota. Adapun media komunikasi yang biasanya digunakan oleh organisasi kemahasiswaan untuk saling berinteraksi antar anggota sebagai berikut, Pakumara dkk (2016: 4) :

1) Komunikasi tatap muka (Face to Face)

Komunikasi tatap muka yang menggunakan panca indera manusia juga dianggap sebagai media komunikasi. Organisasi 
kemahasiswaan biasanya sering melakukan komunikasi secara tatap muka, karena komunikasi secara tatap muka yang dilakukan dianggap akan menciptakan kedekatan dan feedback yang lebih baik dan lebih mudah dimengerti dibandingkan menggunakan teknologi dalam berkomunikasi. Komunikasi tatap muka yang dilakukan oleh seluruh anggota organisasi kemahasiswaan adalah pada saat dilakukannya rapat jika akan melaksanakan suatu program kerja. Rapat yang dilakukan sangat bermanfaat dalam menjaga hubungan yang harmonis antar anggota.

\section{2) Media Komunikasi}

Teknologi informasi memiliki peranan penting di dalam organisasi. Teknologi informasi dan komunikasi yang sangat pesat berkembang saat ini, ditemukannya berbagi penemuan baru berupa teknologi-teknologi modern khususnya dalam bidang internet. Media komunikasi yang digunakan dalam organisasi kemahasiswaan berupa SMS (Short Massage Service), dan WhatsApp dan telepon, media ini digunakan jika dalam keadaan tidak bisa melakukan komunikasi face to face.

\subsection{Ajaran Wacika Parisudha}

Somawati dan Yunitha (2019: 11-12) menyatakan bahwa perkataan dan ucapan sebagai salah satu media untuk membagikan informasi kepada orang lain tentu harus sangat diperhatikan agar tidak memberikan kesesatan informasi. Perkatan sangat perlu diperhatikan dan dipikirkan sebelum dikeluarkan karena perkataan merupakan alat yang penting bagi manusia, guna menyampaikan segala isi hati dan maksud seseorang. Melalui kata-kata seseorang dapat memperoleh suatu pengetahuan, mendapatkan suatu hiburan, serta nasihat-nasihat yang sangat berguna baik bagi seseorang maupun orang lain. Tetapi melalui kata-kata pula, seseorang dapat membuat susah orang lain dan menimbulkan kebencian. Termuat di dalam kitab Sarasamuccaya 118 sebagai berikut :

$$
\begin{aligned}
& \text { samyagalpam ca vaktavyamaviksiptena cetasā } \\
& \text { vākprabandho hi samiāgādvirāgādvā bhavedasan }
\end{aligned}
$$

Terjemahan : Yang patut dikatakan itu hendaklah sesuatu yang membawa kebaikan, hal itu janganlah digembar-gemborkan; berkeinginan disebut pandai bicara; sebab kata-kata itu jika berkepanjangan, ada yang menyebabkan senang ada yang menimbulkan kebencian; tak baik hal serupa itu (Kadjeng, 1997).

Agama Hindu melalui ajarannya menuntun umat, khususnya generasi mudanya untuk selalu menjaga perkataan. Salah satunya adalah ajaran Wacika Parisudha sebagai bagian dari Tri Kaya Parisudha. Wacika Parisudha artinya berkata yang benar atau yang disucikan. Sebagai umat manusia yang sudah dibekali akal pikiran harus selalu berusaha menjaga perkataan. Sebab jika perkataan tidak terkontrol pasti akan dapat menimbulkan bencana, baik bagi diri sendiri maupun orang lain. Berkenaan dengan itu didalam kitab Nitisastra sargah V.3 menyebutkan sebagai berikut: 
Wasita nimittanta manemu laksmi, Wasita nimittanta pati kapangguh, Wasita nimittanta manemu duhka, Wasita nimittanta manemu mitra.

Terjemahan: Dengan perkataan engkau akan mendapatkan bahagia, Dengan perkataan engkau akan menemui kematian, Dengan perkataan engkau mendapat kesengsaraan, Dengan perkataan engkau akan mendapatkan teman.

Makna yang tersirat pada sloka diatas "perkataan yang keluar dari mulut seseorang itu bagaikan paku yang menancap pada sepotong kayu. Bisa saja paku yang telah menancap tersebut ditarik, tetapi bekas tancapan tersebut tidak akan pernah hilang dan selalu berbekas. Bisa saja seseorang telah meminta maaf atas perkataan yang baik secara sengaja maupun tidak sengaja menyinggung perasaan orang lain, tetapi bekas dari ucapan tersebut tidak akan pernah bisa terhapuskan begitu saja dari ingatan orang yang terlanjur tersakiti. Perkataan yang manis dengan maksud baik tentu akan sangat menyenangkan jika didengar oleh setiap orang. Perkataan itu patut timbul dari hati yang tulus, lemah lembut penyamapaiannya dan menyenangkan hati pendengarnya. Untuk dapat berkata yang baik patut dipikirkan terlebih dahulu. Terlanjurnya berkata-kata akan sulit ditarik kembali. Kata-kata merupakan sarana komunikasi yang paling cepat diterima di dalam pergaulan, baik individu dengan individu ataupun kelompok dalam suatu organisasi. Perkataan yang baik diusahakan untuk angawe suka wong len, yaitu mengusahakan kesenangan untuk orang lain, karena orang lainlah yang akan mendengar dan merasakannya. Karena meskipun maksud yang ingin disampaikan adalah baik, tetapi jika disampaikan dengan cara yang tidak sopan belum tentu akan menghasilkan reaksi yang baik dari orang yang mendengarkannya. Seperti yang termuat di dalam kitab Sarasamuccaya 119 sebagai berikut :

Abhyāvahati kalyānamim vividham vāk subhāșitā, Saiva durbhāṣita pumsāmanarthāyopapadyate

Terjemahan : Karena perkataan itu jika maksudnya baik, dan secara baik pula diucapkannya, hanyalah kesenangan yang ditimbulkan olehnya; meski maksudnya baik, jika tidak secara baik diucapkannya, bahkan kepada yang mengucapkannya pun menimbulkan hati duka (Kadjeng, 1997).

Menjaga perkataan yang akan disampaikan kepada orang lain merupakan suatu keniscayaan yang patut dijaga demi kebahagiaan manusia bersama. Apalagi dizaman seperti sekarang ini, dimana semua orang berlomba-lomba menunjukkan eksistensi diri untuk kepentingan diri pribadi, setidaknya tetap menjaga perasaan orang lain tidak boleh terlupakan. Melalui ajaran Wacika Parisudha ini, umat Hindu khususnya generasi muda Hindu diarahkan untuk selalu menjaga kesucian perkataannya. Bahkan termuat dalam kitab Sarasamuccaya 75, kata-kata seperti apa saja yang tidak boleh diniatkan untuk diucapkan, apalagi jika sampai keluar dari mulut seseorang sebagai berikut :

Asatpralāpam pārusyam paicunyamanrtam tathā, Vatvāri vācā rājendra na jalpennānucintayet

Terjemahan : Inilah yang tidak patut timbul dari kata-kata, empat banyaknya, yakni perkataan jahat, perkataan kasar menghardik, perkataan memfitnah, perkataan 
bohong (tak dapat dipercaya); itulah keempatnya harus disingkirkan dari perkataan, jangan diucapkan, jangan dipikir-pikir akan diucapkan (Kadjeng, 1997).

Selain itu, terdapat empat macam perbuatan melalui perkataan yang patut dikendalikan, yaitu : (1) tidak suka mencaci maki, (2) tidak berkatakata kasar pada siapapun, (3) tidak menjelek-jelekkan, apalagi memfitnah makhluk lain, dan (4) tidak ingkar janji atau berkata bohong (Kusuma, 2017).

2.3 Pola Komunikasi Organisasi Kemahasiswaan dalam Penerapan Ajaran Wacika Parisudha

\subsubsection{Proses Komunikasi}

Proses komunikasi adalah suatu proses cara komunikator menyampaikan pesan kepada komunikatornya sehingga terciptanya suatu persamaan makna antara komunikan dengan komunikatornya. Dalam organisasi kemahasiswaan terdapat proses komunikasi yang meliputi:

\section{1) Proses Komunikasi Antar Anggota}

Proses komunikasi antar anggota ini terjalin dari satu individu dengan individu lainnya. Komunikasi yang terjadi dan dilakukan anggota berjalan dengan sendirinya, karena didalam organisasi kemahasiswaan proses komunikasinya tidak dibatasi. Tentu saja dalam komunikasi ini tidak terlepas dari penerapan ajaran Wacika Parisudha, yaitu harus berkata yang baik. Dalam komunikasi antar anggota ini pastinya dilakukan dengan baik oleh individu masingmasing yang tidak akan menyinggung perasaan dari anggota lainnya. Sehingga akan bisa menciptakan komunikasi organisasi yang baik yang tidak melenceng dari ajaran Wacika Parisudha. Jika melalui komunikasi antar anggota sudah menerapkan komunikasi yang baik maka akan mudah menciptakan suasana organisasi yang kondusif.

2) Proses Komunikasi dalam Organisasi Kemahasiswaan

Proses komunikasi di dalam organisasi merupakan suatu proses pengiriman dan penerimaan berbagai pesan organisasi di dalam organisasi formal maupun organisasi informal. Dalam penerapan ajaran Wacika Parisudha di tengah komunikasi organisasi kemahasiswaan tidak lepas dari empat fungsi yang telah dijabarkan sebelumnya, yaitu:

Fungsi Informatif

Biasanya dalam organisasi kemahasiswaan memiliki koordinator yang akan memberikan informasi tentang kegiatan atau hal yang akan dilakukan organisasi tersebut. Misalnya ketika akan mengadakan sebuah rapat, maka akan diberikan informasi mengenai tanggal pelaksanaan rapat tersebut, yang akan memberikan informasi tersebut tentu saja harus menggunakan kata-kata yang baik dan sopan agar pesan yang disampaikan diterima dengan baik. Penerapan ajaran Wacika Parisudha dalam bagian ini bisa dilihat dari informasi yang disampaikan melalui media digital, umumnya si pemberi informasi itu akan mengawali informasi dengan salam yang sopan dan pemilihan kata yang baik. Ini adalah hal dasar yang harus dipahami oleh individu dalam organisasi, pemilihan kata juga sangat 
berpengaruh dalam penyampaian informasi atau dalam komunikasi organisasi.

\section{Fungsi Regulatif}

Dalam organisasi kemahasiswaan biasanya memiliki aturanaturan tertentu yang harus dilakukan oleh semua anggota organisasi kemahasiswaan tersebut. Peraturan-peraturan yang wajib ada dalam organisasi adalah peraturan seperti cara berbicara dan berperilaku yang baik. Berbicara dan berperilaku yang baik sangat penting dalam organisasi agar tidak terjadinya perpecahan di dalam organisasi. Ini juga salah satu dari bentuk penerapan ajaran Wacika Parisudha dalam organisasi. Sebagai mahasiswa yang aktif dalam organisasi tentu saja harus belajar menjaga tutur katanya, karena melalui perkataan seseorang bisa mendapatkan teman dan juga bisa mendapatkan musuh, untuk itu menjaga perkataan merupakan hal yang penting untuk dilakukan.

\section{Fungsi Persuasif}

Dalam organisasi kemahasiswaan pemberian persuasi yang baik adalah hal yang penting untuk dilakukan. Dalam hal ini pemimpin atau anggota dalam organisasi tidak diperbolehkan untuk melakukan persuasi dengan menggunakan perkataan yang bisa menjatuhkan organisasi atau individu lainnya, tidak diperbolehkan juga melakukan persuasi dengan menggunakan cacian atau kata hinaan kepada individu lainnya karena itu sangat bertentangan dengan ajaran Wacika Parisudha. Alangkah baiknya jika saat melakukan persuasi menggunakan kata-kata yang baik dan tidak merugikan oknum lainnya.

\section{Fungsi Integratif}

Dalam organisasi kemahasiswaan penggunaan media dalam komunikasi merupakan hal yang penting. Biasanya yang digunakan adalah Whatsapp. Jika ada informasi mendadak maka penggunaan media komunikasi sangatlah penting untuk digunakan. Tetapi terkadang bahasa komunikasi melalui sebuah media digital bisa menyebabkan kesalahpahaman. Oleh karena itu, sangat penting dalam komunikasi menggunakan media digital untuk menerapkan ajaran Wacika Parisudha. Artinya kata-kata yang digunakn haruslah kata-kata yang tepat dan baik sehingga tidak menyebabkan kesalahpahaman.

3) Pola Komunikasi Organisasi Kemahasiswaan dalam Penerapan Ajaran Wacika Parisudha

Pola komunikasi yang digunakan dalam organisasi kemahasiswaan adalah pola komunikasi semua saluran atau bintang. Pola komunikasi berstruktur bintang berlaku pada seluruh kegiatan seperti rapat dan interaksi diluar rapat yang sifatnya formal maupun informal. Pola bintang diartikan bahwa tidak adanya seorang pemimpin, melainkan seluruh anggota memiliki kekuatan (power) yang sama untuk mempengaruhi anggota yang lainnya. Dalam hal ini, pola komunikasi berstruktur bintang atau semua saluran dapat 
dilihat pada struktur organisasinya yang bersifat non hirarki serta pada saat adanya proses komunikasi secara formal maupun informal. Struktur organisasi kemahasiswaan pada umumnya bersifat non hirarki, yang artinya terdapat kesetaraan kewenangan dan kedudukan yang sama antar anggota dan sama sekali tidak ada batasan-batasan di antara seluruh anggota untuk saling berinteraksi. Oleh karena itu, komunikasi yang terjadi dapat dengan mudah dan efektif sehingga membentuk pola komunikasi yang terjalin antara komunikator dengan komunikan. Dalam menggunakan pola komunikasi semua saluran atau bintang yang memberikan hak sama kepada semua anggota organisasi tidak boleh lepas dari penerapan ajaran Wacika Parisudha yang telah dijabarkan dari awal. Menjaga perkataan dalam organisasi merupakan hal yang tidak boleh dilepaskan baik dalam menggunakan pola komunikasi apapun. Sebagai mahasiswa yang tentunya mengetahui dan paham betul dengan adanya Wacika Parisudha hendaknya mulai belajar untuk mengendalikan perkataannya dan memilih kata-kata yang tepat ketika berkomunikasi yang sesuai dengan konteks situasinya.

Pola komunikasi bintang atau semua saluran yang terjadi di dalam organisasi kemahasiswaan juga dapat dilihat pada saat adanya interaksi di dalam media komunikasi berupa grup-grup WhatsApp, LINE dan telepon. Koordinator sebagai komunikator yang memberikan pesan kepada seluruh organisasi kemahasiswaan tentang adanya informasi-informasi yang formal seperti rapat ataupun informasi-informasi lain tidak boleh lepas dari ajaran Wacika Parisudha. Selain itu, seluruh anggota organisasi juga dapat memberikan timbal balik atau ikut berpartisipasi dalam media komunikasi yang memperlihatkan kesetaraan yang sama antar anggota dalam organisasi kemahasiswaan dengan tetap memperhatikan perkataannya, dengan tidak mengirimkan kata-kata ujaran kebencian yang dapat menyebabkan ketersinggungan satu sama lain dan tentu sangat menyimpang dari ajaran Wachika Parisudha itu sendiri. Penerapan lainnya yaitu dapat dilihat dari interaksi saat rapat dan pada saat melaksanakan berbagai kegiatan organisasi. Dalam melakukan kegiatan, organisasi kemahasiswaan melewati beberapa proses dari mengucapkan salam di dalam grup media sosial, serta mengadakan pertemuan atau rapat, dan diskusi yang dihadiri oleh seluruh anggota organisasi wajib menggunakan perkataan yang sopan guna tercapainya organisasi yang tidak lepas dari dasar-dasar agama salah satunya ajaran Wacika Parisudha itu sendiri.

4) Faktor-faktor yang Mendukung Keberhasilan Pola Komunikasi Organisasi Kemahasiswaan dalam Penerapan Ajaran Wacika Parisudha

Terdapat dua faktor yang mendukung keberhasilan Pola Komunikasi Organisasi Kemahasiswaan dalam Penerapan Ajaran 
Wacika Parisudha yang diklasifikasikan menjadi dua, yakni faktor internal dan eksternal.

\section{Faktor Internal}

Faktor internal merupakan faktor yang bersumber dari dalam. Adapun faktor internal yang mendukung keberhasilan suatu komunikasi antar anggota organisasi kemahasiswaan dalam penerapan Ajaran Wacika Parisudha yaitu kesadaran dari setiap individu mahasiswa yang mengikuti organisasi kemahasiswaan tersebut bahwa sangat penting untuk menjaga perkataan dalam mengikuti sebuah organisasi. Maksud yang baik tetapi diutarakan dengan kata-kata yang kurang bagus maka hal yang tersampaikan juga akan menjadi kurang bagus dan bisa memicu perdebatan dalam organisasi. Jika individu itu sendiri sadar akan pentingnya menjaga perkataan maka untuk mencapai keberhasilan pola komunikasi organisasi kemahasiswaan dalam penerapan ajaran wacika parisudha ini bukanlah suatu hal yang sulit untuk dilakukan. Oleh sebab itu, faktor internal ini memiliki peranan penting dalam membantu keberhasilan pola komunikasi organisasi kemahasiswaan dalam penerapan ajaran wacika parisudha.

\section{Faktor Eksternal}

Faktor eksternal merupakan faktor yang bersumber dari luar. Adapun faktor eksternal yang mendukung keberhasilan suatu komunikasi antar anggota organisasi kemahasiswaan dalam penerapan Ajaran Wacika Parisudha ialah peraturan atau norma yang diterapkan dalam organisasi dan juga para pemimpin atau pengurus dalam organisasi itu sendiri atau bisa juga disebut sebagai lingkungan organisasi. Jika dalam peraturan atau norma dalam organisasi memang terdapat aturan untuk menjaga perkataan seperti pada ajaran wacika parisudha maka anggota dalam organisasi tersebut pastinya sudah wajib untuk mengikuti peraturan tersebut. lingkungan dalam organisasi juga sangat penting jika pemimpin atau pengurus organisasi itu selalu mencontohkan bahwa sangat penting menjaga perkataan dalam organisasi, maka untuk mencapai keberhasilan suatu komunikasi antar anggota organisasi kemahasiswaan dalam penerapan Ajaran Wacika Parisudha bukanlah

\section{PENUTUP} hal yang sulit untuk dilakukan.

Pola komunikasi organisasi kemahasiswaan dalam penerapann ajaran Wacika Parisudha ialah pola komunikasi semua saluran atau bintang. Pola komunikasi berstruktur bintang berlaku pada seluruh kegiatan seperti rapat dan interaksi diluar rapat yang sifatnya formal maupun informal. Pola bintang diartikan bahwa tidak adanya seorang pemimpin, melainkan seluruh anggota memiliki kekuatan (power) yang sama untuk mempengaruhi anggota yang lainnya. Dalam menggunakan pola komunikasi semua saluran atau bintang yang memberikan hak sama kepada semua anggota organisasi tidak boleh lepas dari penerapan ajaran Wacika Parisudha yang telah dijabarkan dari awal. Menjaga perkataan dalam organisasi merupakan hal yang tidak boleh dilepaskan baik dalam menggunakan pola komunikasi apapun. Sebagai 
mahasiswa yang tentunya mengetahui dan paham betul dengan adanya Wacika Parisudha hendaknya mulai belajar untuk mengendalikan perkataannya dan memilih kata-kata yang tepat ketika berkomunikasi yang sesuai dengan konteks situasinya. Terdapat dua faktor yang mendukung keberhasilan Pola Komunikasi Organisasi Kemahasiswaan dalam Penerapan Ajaran Wacika Parisudha yang diklasifikasikan menjadi dua, yakni faktor internal dan eksternal. Faktor internal merupakan faktor yang bersumber dari dalam. Adapun faktor internal yang mendukung keberhasilan suatu komunikasi antar anggota organisasi kemahasiswaan dalam penerapan Ajaran Wacika Parisudha yaitu kesadaran dari setiap individu mahasiswa yang mengikuti organisasi kemahasiswaan tersebut bahwa sangat penting untuk menjaga perkataan dalam mengikuti sebuah organisasi. Faktor eksternal merupakan faktor yang bersumber dari luar. Adapun faktor eksternal yang mendukung keberhasilan suatu komunikasi antar anggota organisasi kemahasiswaan dalam penerapan Ajaran Wacika Parisudha ialah peraturan atau norma yang diterapkan dalam organisasi dan juga para pemimpin atau pengurus dalam organisasi itu sendiri atau bisa juga disebut sebagai lingkungan organisasi.

\section{DAFTAR PUSTAKA}

Bukhori, Baidi. 2016. Kecemasan Berbicara di depan Umum Ditinjau dari Kepercayaan Diri dan Keaktifan dalam Organisasi Kemahasiswaan. Jurnal Komunikasi Islam. Vol. 6 No. 1. http://jki.uinsby.ac.id/index.php/jki/article/view/109/91 diakses pada 13 Januari 2021.

Oviyanti, Fitri. 2016. Peran Organisasi Kemahasiswaan Intrakampus dalam Mengembangkan Kecerdasan Interpersonal Mahasiswa. Journal of Islamic Education Management. Vol. 2 No. 1. http://jurnal.radenfatah.ac.id/index.php/Elidare/article/view/905/747 diakses pada 13 Januari 2021.

Pakumara, Pande Ngurah Raditya Abdi, Amanda, Ni Made Ras, \& Pradipta, Ade Devia. 2017. Pola Komunikasi Organisasi Pasubayan Desa Adat Di Bali. E-Jurnal Medium.Vol. 1 No. 1. http://garuda.ristekbrin.go.id/documents/detail/1057687 diakses pada 12 Januari 2021.

Pratala, Esaka. 2018. Analisis Fungsi Komunikasi Secara Informatif, Regulatif, Persuasif dan Integratif dengan Pelayanan Informasi di Kantor Sekretariat Pd Ibi Provinsi Banten. Jurnal Mozaik. $\quad$ Vol. $10 \quad$ No. 2. https://media.neliti.com/media/publications/299380-analisis-fungsi-komunikasisecara-inform-06d158b9.pdf diakses pada 13 Januari 2021.

Puspa, Ida Ayu Tary, Paramita, Ni Luh Mas, \& Dewi, Anak Agung Nia Listiani. 2020. Pola Komunikasi Keluarga dalam Mengimplementasikan Ajaran Wacika Parisudha. Widya Duta. Vol. $15 \quad$ No.2. http://www.ejournal.ihdn.ac.id/index.php/VidyaDuta/article/view/1829/1473 diakses pada 13 Januari 2021.

Putra, Muhlas Adi \& Ghofur, Muhamad Abdul. 2018. Pola Komunikasi Organisasi Pergerakan Mahasiswa Islam Indonesia (Pmii) di Kota Malang. Jurnal Ilmu Sosial

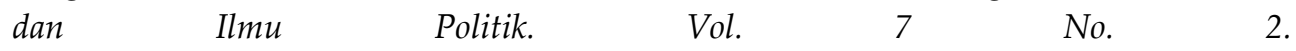
https://publikasi.unitri.ac.id/index.php/fisip/article/view/1428/1003 diakses pada 13 Januari 2021.

Somawati,Ayu Veronikai \& Yunitha, Asri Diantary Ni Made. 2019. Implementasi Ajaran Tri Kaya Parisudha dalam Membangun Karakter Generasi Muda Hindu di Era 
Digital. Jurnal Pasupati Vol. $\quad 6 \quad 1$ No. http://www.ojs.stahdnj.ac.id/index.php/pasupati/article/view/135/64 diakses pada 13 Januari 2021.

Suardika, Nyoman. 2016. Pola Komunikasi Orangtua dengan Anak dalam Mengimplementasikan Ajaran Tri Kaya Parisudha Desa Pakraman Banyuning Kecamatan Buleleng Kabupaten Buleleng. Vidya Samhita Jurnal Penelitian Agama. Vol. 2 No 2. http://www.ejournal.ihdn.ac.id/index.php/vs/article/view/177/156 diakses pada 13 Januari 2021. 